\title{
Supercritical carbon dioxide extract exhibits enhanced antioxidant and anti-inflammatory activities of Physalis peruviana
}

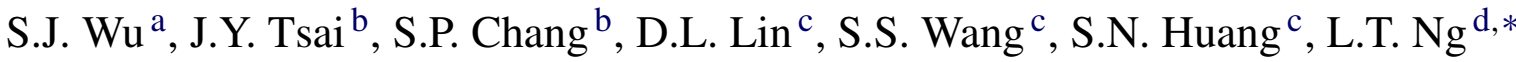 \\ a Department of Health and Nutrition, Chia-Nan University of Pharmacy and Technology, Tainan, Taiwan \\ ${ }^{\mathrm{b}}$ Graduate Institute of Biotechnology, Chia-Nan University of Pharmacy and Technology, Tainan, Taiwan \\ ${ }^{\mathrm{c}}$ Tainan District Agricultural Research and Extension Station, Tainan, Taiwan \\ ${ }^{\mathrm{d}}$ Department of Biotechnology, Tajen University, No. 20 Weishin Road, Yanpu Shiang, Pingtung, Taiwan \\ Received 26 April 2006; accepted 26 May 2006 \\ Available online 2 June 2006
}

\begin{abstract}
Physalis peruviana L. (PP) is a medicinal herb widely used in folk medicine. In this study, supercritical carbon dioxide $\left(\mathrm{SFE}^{-\mathrm{CO}} \mathrm{O}_{2}\right)$ method was employed to obtain three different PP extracts, namely SCEPP-0, SCEPP-4 and SCEPP-5. The total flavonoid and phenol concentrations, as well as antioxidant and anti-inflammatory activities of these extracts were analyzed and compared with aqueous and ethanolic PP extracts. Among all the extracts tested, SCEPP-5 demonstrated the highest total flavonoid $(234.63 \pm 9.61 \mathrm{mg} / \mathrm{g})$ and phenol $(90.80 \pm 2.21 \mathrm{mg} / \mathrm{g}) \mathrm{contents}$. At concentrations $0.1-30 \mu \mathrm{g} / \mathrm{ml}$, SCEPP-5 also demonstrated the strongest superoxide anion scavenging activity and xanthine oxidase inhibitory effect. At $30 \mu \mathrm{g} / \mathrm{ml}$, SCEPP-5 significantly prevented lipopolysaccharide (LPS; $1 \mu \mathrm{g} / \mathrm{ml}$ )-induced cell cytotoxicity in murine macrophage (Raw 264.7) cells. At $10-50 \mu \mathrm{g} / \mathrm{ml}$, it also significantly inhibited LPS-induced NO release and $\mathrm{PGE}_{2}$ formation in a dose-dependent pattern. SCEPP-5 at $30 \mu \mathrm{g} / \mathrm{ml}$ remarkably blocked the LPS induction of inducible nitric oxide synthase (iNOS) and cyclooxygenase-2 (COX-2) expression. Taken together, these results suggest that SCEPP-5, an extract of SFE- $\mathrm{CO}_{2}$, displayed the strongest antioxidant and anti-inflammatory activities as compared to other extracts. Its protection against LPS-induced inflammation could be through the inhibition of iNOS and COX-2 expression.
\end{abstract}

(c) 2006 Elsevier Ireland Ltd. All rights reserved.

Keywords: Supercritical fluid extraction; Physalis peruviana; Antioxidant; Anti-inflammatory; iNOS; COX-2

\section{Introduction}

Free radicals have been regarded as a fundamental cause of different kinds of diseases, including aging, coronary heart disease, inflammation, stroke, diabetes mellitus, rheumatic disease, liver disorders, renal failure and cancer (Bulkley, 1983; Cheng et al., 2003; Dormandy, 1983). Among inflammatory cells, polymorphonuclear leukocytes are particularly adept at generating and releasing reactive oxygen species (ROS) and reactive nitrogen species (RNS), including free radicals such as ${ }^{\bullet} \mathrm{O}_{2}{ }^{-}$(superoxide anion), $\bullet$ OH (hydroxyl radical), $\mathrm{H}_{2} \mathrm{O}_{2}$ (hydrogen peroxide), $\mathrm{NO}$ (nitric oxide) and ${ }^{1} \mathrm{O}_{2}$ (singlet oxygen) (Ramos et al., 1992; Steineck et al., 1992). The excessively produced ROS can injure cellular biomolecules such as nucleic acids, proteins, carbohydrates, and lipids, causing cellular and

\footnotetext{
* Corresponding author. Tel.: +886 8 7624002x450; fax: +886 87621645 . E-mail address: 1thuang@mail.tajen.edu.tw (L.T. Ng).
}

tissue damage, which in turn augments the state of inflammation (Trenam et al., 1992).

Lipopolysaccharide (LPS), which is a component of the cell walls of gram-negative bacteria, can activate cellular signals of macrophages, hepatocytes and monocytes during inflammation and infection (Bitler et al., 2005; Ganey et al., 2001; Ulevtich and Tobias, 1995). Stimulation of murine macrophages by LPS results in the expression of inducible nitric oxide synthase (iNOS), which catalyze the production of a large amount of NO from L-arginine and molecular oxygen (Hibbs et al., 1987). In addition, prostaglandins $\left(\mathrm{PGE}_{2}\right)$ are key inflammatory mediators that are converted from arachidonic acid by cyclooxygenase. Cyclooxygenase-2 (COX-2) is responsible for the elevated production of $\mathrm{PGE}_{2}$ during inflammation (Crofford et al., 2000; Mitchell et al., 1995).

Supercritical fluid extraction (SFE) can offer special advantages over conventional solvent extraction such as increased selectivity, expeditiousness and environmental friendly (Hu et al., 2004; Shu et al., 2004). Carbon dioxide $\left(\mathrm{CO}_{2}\right)$, which has 
the advantage of being chemically inert, is the standard choice of solvent for SFE in natural product (Leal et al., 2003), food, flavor and pharmaceutical industries (Leal et al., 2003; Wang et al., 2005; Yang et al., 2002). Extracts prepared by SFE was found to have a significantly higher antioxidant activities than extracts obtained by conventional means (Leal et al., 2003; Schwarz et al., 1992; Tipsrisukond et al., 1998; Yang et al., 2002). Supercritical $\mathrm{CO}_{2}$ extracts of Perna canaliculus also showed antiinflammatory activity (Halpern, 2000).

Physalis peruviana L. (PP) is widely used in folk medicine for treating diseases such as malaria, asthma, hepatitis, dermatitis, diuretic and rheumatism (Perry, 1980; Wu et al., 2004a). Its extract can also be used for preparing health drink. Our previous studies demonstrated that ethanol extract of PP possessed potent antioxidant activities (Wu et al., 2005) and anti-proliferative effect on hepatoma (Hep G2) cells (Wu et al., 2004a,b). The antioxidant and anti-inflammatory activities of PP extract prepared by SFE have never been evaluated. In this study, our aim was to examine a more effective extraction method in preparing PP extract while not affecting its antioxidant and antiinflammatory activities.

\section{Materials and methods}

\subsection{Chemicals}

Dimethyl sulfoxide (DMSO), penicillin, streptomycin, anti$\beta$-actin, 3-(4,5-dimethyl-thiazol-2-yl)-2,5-diphenyl-tertazolium bromide (MTT), lipopolysaccharide (LPS; from Escherichia coli strain) were purchased from Sigma Chemical Co. (St. Louis, MO, USA). Fetal bovine serum (FBS) and DMEM medium were obtained from GIBCO BRL (Gaithersburg, MD, USA). The ELISA kit used for the determination of prostaglandin $\mathrm{E}_{2}$ $\left(\mathrm{PGE}_{2}\right)$ was purchased from Cayman Chemical Co. (Ann Arbor, MI, USA). The anti-COX-2 and anti-iNOS bodies were purchased from Santa Cruz Biotechnology (Santa Cruz, CA, USA). Anti-mouse IgG antibody was obtained from Promega (Madison, WI, USA). Carbon dioxide with purity $>99 \%$ (food grade) was supplied by Yun Shan Gases Inc. (Tainan, Taiwan). All other chemicals and reagents used were of analytical grade.

\subsection{Plant materials}

The plant material of Physalis peruviana (PP) was obtained from Tainan District Agriculture Improvement Station, Taiwan. Its authenticity was confirmed by Prof. C.C. Lin from the Graduate Institute of Natural Products, Kaohsiung Medical University, Taiwan. The PP leaves were dried and ground to sawdust form, which was then kept in an air-tight brown bottle until use.

\subsection{Hot water extraction}

One hundred grams (100 g) of PP powder was extracted with 11 of boiling water for $1 \mathrm{~h}$. The extract was filtered with filter paper (Advantec No. 1, Japan) while the residue was re-extracted under the same conditions twice. The filtrates obtained from three separate extractions were combined, concentrated and then lyophilized. The dried aqueous PP extract (HWEPP) was collected, weighed and stored at $4{ }^{\circ} \mathrm{C}$ until use.

\subsection{Ethanol extraction}

One hundred grams (100 g) of PP powder was soaked with 11 of ethanol $(95 \%)$ at room temperature for 6 days. After filtering the extract with filter paper (Advantec No. 1, Japan), the residue was further extracted under the same conditions twice. The filtrates collected from three separate extractions were combined, concentrated and lyophilized. The dried ethanol PP extract (EEPP) was collected, weighed and stored at $4{ }^{\circ} \mathrm{C}$ until use.

\subsection{Preparation of Physalis peruviana extract using supercritical fluid extraction (SFE)}

The extraction was performed according to procedures described by Yang et al. (2002). In brief, $5 \mathrm{~g}$ of PP powder was taken and placed in the SFE cartridge. The PP extract was mixed without or with $4 \%$ or $5 \%$ ethanol as modifier, and then continuously fed counter currently into a supercritical fluid system (Applied Separations, Allentown, PA, USA) together with liquid $\mathrm{CO}_{2}$. The SFE process consisted of a static extraction time of $5 \mathrm{~min}$ followed by a dynamic extraction for $30 \mathrm{~min}$ to $1 \mathrm{~h}$. The restrictor temperature and extraction pressure were set at $60{ }^{\circ} \mathrm{C}$ and $400 \mathrm{bar}$, respectively. Extracts were collected in $10 \mathrm{ml}$ ethanol. After removing the solvent, the dried SFE- $\mathrm{CO}_{2}$ PP extract was collected, weighed and subjected to subsequent chemical and biological analyses. Sample SCEPP-0 was obtained without ethanol as modifier, while SCEPP-4 and SCEPP-5 were obtained with $4 \%$ and $5 \%$ ethanol as modifier, respectively.

\subsection{Total flavonoid analysis}

The total flavonoid content of PP extract was determined according to colorimetric method as described by Zou et al. (2004). In brief, $0.5 \mathrm{ml}$ of sample solution was mixed with $2 \mathrm{ml}$ of distilled water and subsequently with $0.15 \mathrm{ml}$ of a $5 \% \mathrm{NaNO}_{2}$ solution. After $6 \mathrm{~min}$ of incubation, $0.15 \mathrm{ml}$ of $10 \% \mathrm{AlCl}_{3}$ solution was added and allowed to stand for $6 \mathrm{~min}$, then $2 \mathrm{ml}$ of $4 \% \mathrm{NaOH}$ solution was added to the mixture. Immediately after water was added to the sample to bring to the final volume of $5 \mathrm{ml}$, the mixture was thoroughly mixed and allowed to stand for another $15 \mathrm{~min}$. The mixture absorbance was determined at wavelength $510 \mathrm{~nm}$. Rutin was used as a standard compound for the quantification of total flavonoid content. All values were expressed in milligrams of rutin equivalents per gram of all extracts.

\subsection{Total phenol analysis}

The total phenol content of PP was analyzed according to the Folin-Ciocalteu method as described by Cliffe et al. (1994). In brief, after PP extracts and standards were well mixed with $2.5 \mathrm{ml}$ of distilled water and $0.5 \mathrm{ml}$ of the Folin-Ciocalteu stock reagent, $1.0 \mathrm{ml}$ of $\mathrm{Na}_{2} \mathrm{CO}_{3}$ reagent $(75 \mathrm{~g} / \mathrm{l})$ was added to the 
mixture and then incubated at room temperature for $30 \mathrm{~min}$. The mixture absorbance was measured spectrophotometrically at wavelength $765 \mathrm{~nm}$. The total phenol content was expressed in milligrams of gallic acid equivalents per gram of PP extract.

\subsection{Cytochrome c test}

Enzymatic formation of superoxide anions was assayed by the reduction of cytochrome $c$ method (McCord and Fridovich, 1969). Ten milligrams of samples were dissolved in $1 \mathrm{ml}$ of distilled water or DMSO and then diluted with $50 \mathrm{mM}$ phosphate buffer ( $\mathrm{pH} 7.8$ ) to various concentrations $(0.1-30 \mu \mathrm{g} / \mathrm{ml})$, followed by adding 0.07 units $/ \mathrm{ml}$ of xanthine oxidase, $100 \mu \mathrm{M}$ of xanthine and $50 \mu \mathrm{M}$ of cytochrome $c$ to these samples. After incubating at room temperature for $3 \mathrm{~min}$, they were spectrophotometrically determined at wavelength $550 \mathrm{~nm}$.

\subsection{Xanthine oxidase inhibition test}

Xanthine oxidase activity was estimated by the formation of uric acid from xanthine (Chang et al., 1994). Ten milligrams of samples were dissolved in $1 \mathrm{ml}$ distilled water or DMSO, and then diluted with $50 \mathrm{mM} \mathrm{KH}_{2} \mathrm{PO}_{4}$ buffer ( $\mathrm{pH}$ 7.8) to various concentrations $(0.1-30 \mu \mathrm{g} / \mathrm{ml})$. After $100 \mu \mathrm{M}$ of xanthine and $20 \mu l$ of xanthine oxidase ( 0.4 units) were added, samples were incubated for $3 \mathrm{~min}$ at room temperature. Superoxide formation was counted by measuring uric acid production by spectrophotometry at $295 \mathrm{~nm}$.

\subsection{Cell culture}

Raw 264.7, a murine macrophage cell line, was obtained from the American Type Culture Collection (ATCC No. TIB 71, Rockville, MD). Cells were grown in 90\% DMEM supplemented with $10 \%$ FBS, 100 units $/ \mathrm{ml}$ penicillin and $100 \mu \mathrm{g} / \mathrm{ml}$ streptomycin. They were maintained at $37{ }^{\circ} \mathrm{C}$ in a humidified atmosphere of $5 \% \mathrm{CO}_{2}$.

\subsection{MTT assay for cell viability}

Cytotoxicity studies were performed in 96-well plates. Raw 264.7 cells were cultured at $5 \times 10^{5}$ cells per well in 96-well plates containing $100 \mu \mathrm{l}$ of DMEM medium. After an overnight incubation, SCEPP-5 or EEPP was added, the plates were further incubated for $24 \mathrm{~h}$. Cells were washed once before adding $50 \mu \mathrm{l}$ of FBS-free medium containing MTT $(5 \mathrm{mg} / \mathrm{ml})$. After $4 \mathrm{~h}$ of incubation at $37^{\circ} \mathrm{C}$, the medium was discarded and the formazan blue that formed in the cells was dissolved in DMSO. The optical density was measured at $550 \mathrm{~nm}$.

\subsection{Nitrite determination}

After incubating the cells with either LPS $(1 \mu \mathrm{g} / \mathrm{ml})$ or LPS plus various concentrations of SCEPP- $5(10,30$ and $50 \mu \mathrm{g} / \mathrm{ml})$ for $24 \mathrm{~h}$, the supernatant was removed from the cultures. The nitrite accumulated in culture medium was measured as an indicator of NO production based on the Griess reaction (Heiss et al.,
2001). Briefly, $100 \mu l$ of each supernatant was mixed with the same volume of Griess reagent [ $1 \%$ sulfanilamide in $5 \%$ phosphoric acid and $0.1 \%$ naphthylethylenediamine dihydrocloride in water], and then incubated at room temperature for $10 \mathrm{~min}$, the absorbance was measured at $550 \mathrm{~nm}$ using an ELISA reader. The amount of NO production in the samples was measured with the sodium nitrite serial dilution standard curve.

\subsection{3. $P G E_{2}$ assay}

The prostaglandin $\mathrm{E}_{2}\left(\mathrm{PGE}_{2}\right)$ level in the supernatant of the culture medium was quantified using ELISA kits according to the manufacturer instructions.

\subsection{Western immunoblot analysis}

Cellular proteins were extracted from the control, SCEPP$5(10$ and $30 \mu \mathrm{g} / \mathrm{ml})$ alone, LPS $(1 \mu \mathrm{g} / \mathrm{ml})$ alone or LPS plus SCEPP-5 $(10$ and $30 \mu \mathrm{g} / \mathrm{ml})$ for $24 \mathrm{~h}$. Cytoplasmic extracts were prepared by the extraction lysis buffer $(10 \mathrm{mM}$ Tris-HCl, $\mathrm{pH}$ $7.5,0.1 \%$ NP- $40,0.5 \%$ sodium deoxycholate, $0.1 \%$ SDS, $1 \mathrm{mM}$ sodium orthovanate and $120 \mathrm{mM}$ sodium chloride) containing $1 \mathrm{mM}$ phenylmethylsulfonyl fluoride, $10 \mu \mathrm{g} / \mathrm{ml}$ leupeptin and $1 \mu \mathrm{g} / \mathrm{ml}$ aprotonin (Sigma Chemical Co., St. Louis, MO, USA). Lysates were centrifuged at $10,000 \times g$ for $10 \mathrm{~min}$. Equal amounts of lysate protein $(50 \mu \mathrm{g} / \mathrm{lane})$ were loaded onto SDSpolyacrylamide gels and electrophoretically transferred to a PVDF membrane (Bio-Rad Laboratories, Hercules, CA, USA). After inhibiting the non-specific binding sites with $5 \%(\mathrm{w} / \mathrm{v})$ skim milk in $0.1 \%(\mathrm{v} / \mathrm{v})$ Tween 20 containing PBS (PBST) for $1 \mathrm{~h}$ at room temperature, the membrane was incubated with the specific primary antibodies [namely anti-iNOS (1:500), antiCOX-2 (1:500) and anti- $\beta$-actin (1:5000) antibodies] in 5\% $(\mathrm{w} / \mathrm{v})$ skim milk in PBST for $1 \mathrm{~h}$ at room temperature. Antibody recognition was detected with the respective secondary antibody, i.e. anti-mouse $\operatorname{IgG}$ antibody linked to the horseradish peroxidase. Antibody-bound proteins were detected by the ECL western blotting analysis system (Amersham, Aylesbury, UK). The expression of $\beta$-actin was used as a control.

\subsection{Statistical analysis}

Data were presented as means \pm standard deviations (S.D.) from three independent experiments. Values were evaluated by one-way ANOVA, followed by Duncan's multiple range tests using the Statistical Analysis System (SAS Institute, Cary, NC, USA). Control and treatment groups were compared among themselves using Student's $t$-test. Differences were considered significant when $P$-value was $<0.05$.

\section{Results}

\subsection{Yield of Physalis peruviana extract obtained by different extraction methods}

The yields of PP extracts obtained by hot water (HWEPP) and ethanol (EEPP) were $20.7 \%$ and $24.0 \%$, respectively (Table 1). A 
Table 1

Effects of extraction method on the yield of Physalis peruviana extract

\begin{tabular}{lrl}
\hline Treatment & \multicolumn{1}{c}{ Yield $(\%)$} & Color \\
\hline HWEPP & $20.73 \pm 1.50 \mathrm{~b}$ & Light yellow \\
EEPP & $24.00 \pm 2.00 \mathrm{a}$ & Brown \\
SCEPP-0 & $3.60 \pm 0.32 \mathrm{e}$ & Yellow \\
SCEPP-4 & $6.88 \pm 1.45 \mathrm{~d}$ & Yellow brown \\
SCEPP-5 & $15.47 \pm 0.68 \mathrm{c}$ & Yellow green \\
\hline
\end{tabular}

Each data represents the mean \pm S.D. of three independent experiments. Values within the same column with the different letters were significantly different at $P<0.05$ as analyzed by Duncan's multiple range tests.

considerable variation in yield was noted in different conditions of SFE. The yield obtained by SFE- $\mathrm{CO}_{2}$ extraction appears to increase with increasing the percentage of modifier, from $6.88 \%$ for $4 \%$ ethanol (SCEPP-4) to $15.47 \%$ for $5 \%$ ethanol (SCEPP$5)$. All extracts showed coloration, however, they vary with the experimental conditions, which could affect the overall product quality.

\subsection{Total flavonoid and phenol contents of Physalis peruviana extracts}

Results showed that EEPP possessed a higher total flavonoid and phenol contents than HWEPP and SCEPP-0 extracts, but was lower than SCEPP-4 and SCEPP-5. With increasing concentration of ethanol as modifier in SFE- $\mathrm{CO}_{2}$, an increase in total flavonoid and phenol contents was noted. Among the different extracts, SCEPP-5 displayed the highest concentration in total flavonoid $(234.63 \pm 9.61 \mathrm{mg} / \mathrm{g})$ and phenol $(90.80 \pm 2.21 \mathrm{mg} / \mathrm{g})$ contents (Table 2).

\subsection{Free radical scavenging activity}

Results on free radical scavenging activity of different PP extracts are shown in Table 3. The scavenging effect was found to increase with increasing concentration of PP extracts regardless of the nature of the extract. At concentrations $0.10-30.0 \mu \mathrm{g} / \mathrm{ml}$, PP extracts showed a scavenging rate ranges from $12.19 \pm 1.87 \%$ to $69.48 \pm 3.34 \%$. The SCEPP-5 exhibited a scavenging effect of $47.75 \%$ at $1.0 \mu \mathrm{g} / \mathrm{ml}, 60.51 \%$ at $10 \mu \mathrm{g} / \mathrm{ml}$, and $69.48 \%$ at $30 \mu \mathrm{g} / \mathrm{ml}$, which were more active than that of $\alpha$-tocopherol at the same concentration. With its low $\mathrm{IC}_{50}$ value $(6.78 \mu \mathrm{g} / \mathrm{ml})$, SCEPP-5 has demonstrated to be potent in scavenging superoxide anions (Table 4). On the other hand, HWEPP,

Table 2

Total flavonoid and phenol contents of different Physalis peruviana extracts

\begin{tabular}{lcc}
\hline Treatment & Flavonoids $(\mathrm{mg} / \mathrm{g})$ & Phenols $(\mathrm{mg} / \mathrm{g})$ \\
\hline HWEPP & $40.45 \pm 0.10 \mathrm{e}$ & $19.64 \pm 0.09 \mathrm{~d}$ \\
EEPP & $84.24 \pm 0.60 \mathrm{c}$ & $88.81 \pm 0.01 \mathrm{~b}$ \\
SCEPP-0 & $60.04 \pm 0.08 \mathrm{~d}$ & $14.53 \pm 1.30 \mathrm{e}$ \\
SCEPP-4 & $193.06 \pm 4.26 \mathrm{~b}$ & $73.95 \pm 4.20 \mathrm{c}$ \\
SCEPP-5 & $234.63 \pm 9.61 \mathrm{a}$ & $90.80 \pm 2.21 \mathrm{a}$
\end{tabular}

Each data represents the mean \pm S.D. of three independent experiments. Values within the same column with the different letters were significantly different at $P<0.05$ as analyzed by Duncan's multiple range tests.
Table 3

Superoxide scavenging activity of hot water (HWEPP), ethanol (EEPP) and supercritical $\mathrm{CO}_{2}$ (SCEPP-5) extracts of Physalis peruviana

\begin{tabular}{lcl}
\hline Samples & Concentration $(\mu \mathrm{g} / \mathrm{ml})$ & Scavenging rate $(\%)$ \\
\hline HWEPP & 0.1 & $12.19 \pm 1.87 \mathrm{~d}$ \\
EEPP & 0.1 & $22.93 \pm 2.24 \mathrm{c}$ \\
SCEPP-5 & 0.1 & $29.24 \pm 1.07 \mathrm{~b}$ \\
$\alpha$-Tocopherol & 0.1 & $39.25 \pm 0.66 \mathrm{a}$ \\
HWEPP & 1.0 & $28.25 \pm 0.91 \mathrm{c}$ \\
EEPP & 1.0 & $29.93 \pm 1.30 \mathrm{c}$ \\
SCEPP-5 & 1.0 & $47.75 \pm 0.33 \mathrm{a}$ \\
$\alpha$-Tocopherol & 1.0 & $40.34 \pm 0.58 \mathrm{~b}$ \\
HWEPP & 10 & $43.79 \pm 1.48 \mathrm{c}$ \\
EEPP & 10 & $49.12 \pm 0.66 \mathrm{~b}$ \\
SCEPP-5 & 10 & $60.51 \pm 1.55 \mathrm{a}$ \\
$\alpha$-Tocopherol & 10 & $49.89 \pm 0.79 \mathrm{~b}$ \\
HWEPP & 30 & $49.04 \pm 1.57 \mathrm{c}$ \\
EEPP & 30 & $67.78 \pm 2.26 \mathrm{ab}$ \\
SCEPP-5 & 30 & $69.48 \pm 3.34 \mathrm{a}$ \\
$\alpha$-Tocopherol & 30 & $63.42 \pm 0.77 \mathrm{~b}$ \\
\hline
\end{tabular}

Each data represents the mean \pm S.D. of three independent experiments. Values within the same concentration with the different letters were significantly different at $P<0.05$ as analyzed by Duncan's multiple range tests.

a more polar extract, exhibited a weak superoxide radical scavenging activity.

\subsection{Xanthine oxidase inhibition test}

Results showed that all extracts exhibited inhibitory activity against the xanthine oxidase-induced superoxide formation in a concentration-dependent manner (Table 5). At concentrations $0.1-30 \mu \mathrm{g} / \mathrm{ml}$, all extracts displayed an inhibitory rate ranging from $0.80 \%$ to $67.22 \%$. The order of xanthine oxidase inhibition effect was $\alpha$-tocopherol $>$ SCEPP-5 > EEPP > HWEPP. With the exception of HWEPP, SCEPP-5 and EEPP showed a relatively closed $\mathrm{IC}_{50}$ value to that of $\alpha$-tocopherol $(6.76 \mu \mathrm{g} / \mathrm{ml})$. However, SCEPP-5 $(7.48 \mu \mathrm{g} / \mathrm{ml})$ showed a slightly lower IC $_{50}$ value than $\operatorname{EEPP}(7.90 \mu \mathrm{g} / \mathrm{ml})$.

\subsection{Effect of SCEPP-5 and EEPP on Raw 264.7 cell viability}

MTT assay was used to determine the effect of SCEPP-5 and EEPP on cell viability. In brief, cell numbers were measured after $24 \mathrm{~h}$ of incubation with SCEPP-5 or EEPP at various concentrations $(10,30$ and $50 \mu \mathrm{g} / \mathrm{ml})$ in the presence or absence of LPS $(1 \mu \mathrm{g} / \mathrm{ml})$. Results showed that in the LPS stimulated cells,

Table 4

$\mathrm{IC}_{50}$ values of different Physalis peruviana extracts

\begin{tabular}{lcc}
\hline Treatment & \multicolumn{2}{l}{$\mathrm{IC}_{50}$ value $(\mu \mathrm{g} / \mathrm{ml})$} \\
\cline { 2 - 3 } & Cytochrome $c$ test & Xanthine oxidase inhibition test \\
\hline HWEPP & $>50.00$ & $>50.00$ \\
EEPP & 17.61 & 7.90 \\
SCEPP-5 & 6.78 & 7.48 \\
$\alpha$-Tocopherol & 6.81 & 6.76
\end{tabular}


Table 5

Xanthine oxidase inhibition activity of hot water (HWEPP), ethanol (EEPP) and supercritical $\mathrm{CO}_{2}$ (SCEPP-5) extracts of Physalis peruviana

\begin{tabular}{lcc}
\hline Samples & Concentration $(\mu \mathrm{g} / \mathrm{ml})$ & Inhibition rate $(\%)$ \\
\hline HWEPP & 0.1 & $0.80 \pm 0.15 \mathrm{~d}$ \\
EEPP & 0.1 & $9.89 \pm 0.16 \mathrm{c}$ \\
SCEPP-5 & 0.1 & $30.69 \pm 2.13 \mathrm{~b}$ \\
$\alpha$-Tocopherol & 0.1 & $37.01 \pm 1.72 \mathrm{a}$ \\
HWEPP & 1.0 & $5.87 \pm 0.66 \mathrm{c}$ \\
EEPP & 1.0 & $38.42 \pm 1.43 \mathrm{~b}$ \\
SCEPP-5 & 1.0 & $40.10 \pm 1.27 \mathrm{~b}$ \\
$\alpha$-Tocopherol & 1.0 & $49.96 \pm 1.25 \mathrm{a}$ \\
HWEPP & 10 & $6.38 \pm 0.44 \mathrm{~b}$ \\
EEPP & 10 & $57.76 \pm 1.29 \mathrm{a}$ \\
SCEPP-5 & 10 & $58.00 \pm 1.50 \mathrm{a}$ \\
$\alpha$-Tocopherol & 10 & $58.96 \pm 1.44 \mathrm{a}$ \\
HWEPP & 30 & $30.90 \pm 3.11 \mathrm{c}$ \\
EEPP & 30 & $62.05 \pm 0.91 \mathrm{~b}$ \\
SCEPP-5 & 30 & $67.22 \pm 1.58 \mathrm{a}$ \\
$\alpha$-Tocopherol & 30 & $70.87 \pm 1.41 \mathrm{a}$ \\
\hline
\end{tabular}

Each data represents the mean \pm S.D. of three independent experiments. Values within the same concentration with the different letters were significantly different at $P<0.05$ as analyzed by Duncan's multiple range tests.

the percentage of cell viability in $30 \mu \mathrm{g} / \mathrm{ml}$ SCEPP- 5 was better than $50 \mu \mathrm{g} / \mathrm{ml}$ EEPP. It retained $>98.00 \%$ cell viability in LPStreated cells (Fig. 1). Hence, SCEPP-5 was selected for further anti-inflammatory studies.

\subsection{Effect of SCEPP-5 on NO production}

To investigate the effect of SCEPP-5 on NO production, we measured the accumulation of nitrite, the stable end product of $\mathrm{NO}$, in the culture media using Griess reagent. In brief, cells were stimulated with LPS $(1 \mu \mathrm{g} / \mathrm{ml})$ for $24 \mathrm{~h}$ to evoke nitric oxide (NO) synthesis. LPS stimulation showed an over 10 -fold (ca. $41 \mu \mathrm{M}$ ) increase in NO production. However, coincubation of cells with SCEPP-5 at different concentrations (10, 30 and $50 \mu \mathrm{g} / \mathrm{ml}$ ) plus LPS resulted in a dose-dependent reduction of NO formation (Table 6). The concentration of NO in the medium of cell treated with 30 and $50 \mu \mathrm{g} / \mathrm{ml} \mathrm{SCEPP-5} \mathrm{was}$ found to return to near the level of that of the unstimulated control group.

Table 6

Effects of SCEPP-5 on LPS $(1 \mu \mathrm{g} / \mathrm{ml})$-induced nitric oxide release and $\mathrm{PGE}_{2}$ production in Raw 264.7 cells

\begin{tabular}{lcc}
\hline Sample & Nitric oxide $(\mu \mathrm{M})$ & PGE $_{2}(\mathrm{ng} / \mathrm{ml})$ \\
\hline Control & $2.83 \pm 0.01 \mathrm{~d}$ & $0.55 \pm 0.10 \mathrm{~d}$ \\
LPS & $41.44 \pm 0.03 \mathrm{a}$ & $3.92 \pm 0.31 \mathrm{a}$ \\
LPS $+10 \mu \mathrm{g} / \mathrm{ml}$ SCEPP-5 & $8.23 \pm 0.01 \mathrm{~b}$ & $1.50 \pm 0.16 \mathrm{~b}$ \\
LPS $+30 \mu \mathrm{g} / \mathrm{ml} \mathrm{SCEPP-5}$ & $4.09 \pm 0.07 \mathrm{c}$ & $0.99 \pm 0.15 \mathrm{c}$ \\
LPS $+50 \mu \mathrm{g} / \mathrm{ml} \mathrm{SCEPP-5}$ & $3.99 \pm 0.04 \mathrm{c}$ & $0.93 \pm 0.05 \mathrm{c}$
\end{tabular}

Each data represents the mean \pm S.D. of three independent experiments. Values within the same column with the different letters were significantly different at $P<0.05$ as analyzed by Duncan's multiple range tests.
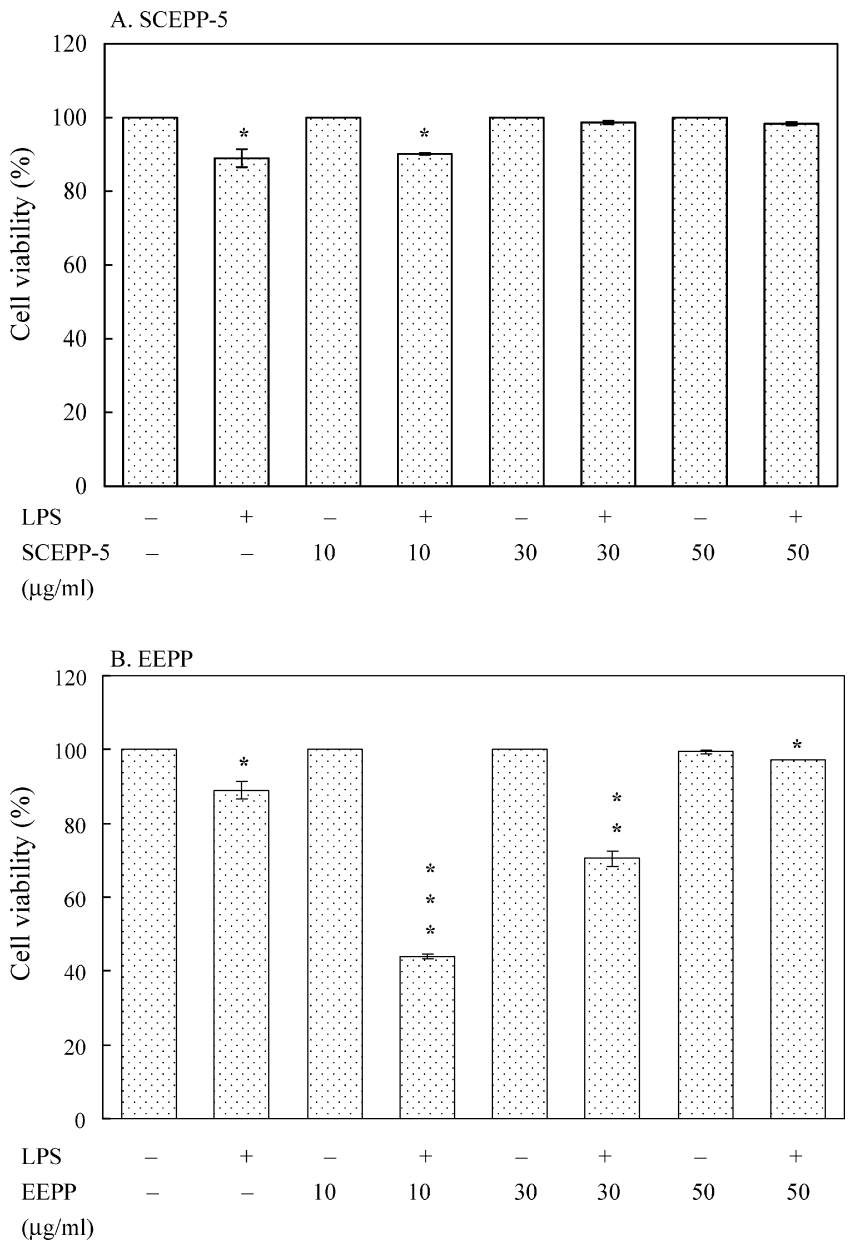

Fig. 1. Effect of SCEPP-5 or EEPP on Raw 264.7 cell viability with or without LPS-stimulation. Cells were treated with 0, 10, 30 and $50 \mu \mathrm{g} / \mathrm{ml} \mathrm{SCEPP-5} \mathrm{(A)}$ or EEPP (B) in the presence or absence of LPS $(1 \mu \mathrm{g} / \mathrm{ml})$ for $24 \mathrm{~h}$. Cell viability was determined by the MTT assay. Values represent the mean \pm S.D. of three independent experiments. The asterisk indicates a significant difference from untreated cells (control) as analyzed by Student's $t$-tests $\left({ }^{*} P<0.05 ;{ }^{* *} P<0.01\right.$; $\left.{ }^{* * *} P<0.001\right)$.

\subsection{Effect of SCEPP on $P G E_{2}$ synthesis}

$\mathrm{PGE}_{2}$ release indicates an inflammatory response of cells. To examine the effect of SCEPP-5 on $\mathrm{PGE}_{2}$ production in Raw 264.7 cells, cells were stimulated with $1 \mu \mathrm{g} / \mathrm{ml}$ LPS alone or LPS plus various concentrations of SCEPP-5 (10, 30 and $50 \mu \mathrm{g} / \mathrm{ml})$ for $24 \mathrm{~h}$. Results showed a dramatic increase in $\mathrm{PGE}_{2}$ production $(3.92 \pm 0.30 \mathrm{ng} / \mathrm{ml})$ in the LPS-stimulated cells as compared to the control group $(0.55 \pm 0.10 \mathrm{ng} / \mathrm{ml})$ (Table 6). However, co-treatment of cells with LPS plus SCEPP-5 demonstrated a significant suppression in the LPS-induced $\mathrm{PGE}_{2}$ production. SCEPP-5 at concentrations 30 and $50 \mu \mathrm{g} / \mathrm{ml}$ strongly blocked the LPS-induced $\mathrm{PGE}_{2}$ production.

\subsection{Effect of SCEPP-5 on iNOS and COX-2 expression}

To examine the effect SCEPP-5 on iNOS and COX-2 expression, cells were stimulated with control (0.1\% DMSO), $1 \mu \mathrm{g} / \mathrm{ml}$ LPS alone or $1 \mu \mathrm{g} / \mathrm{ml}$ LPS plus SCEPP-5 (10, 30 and $50 \mu \mathrm{g} / \mathrm{ml})$ 


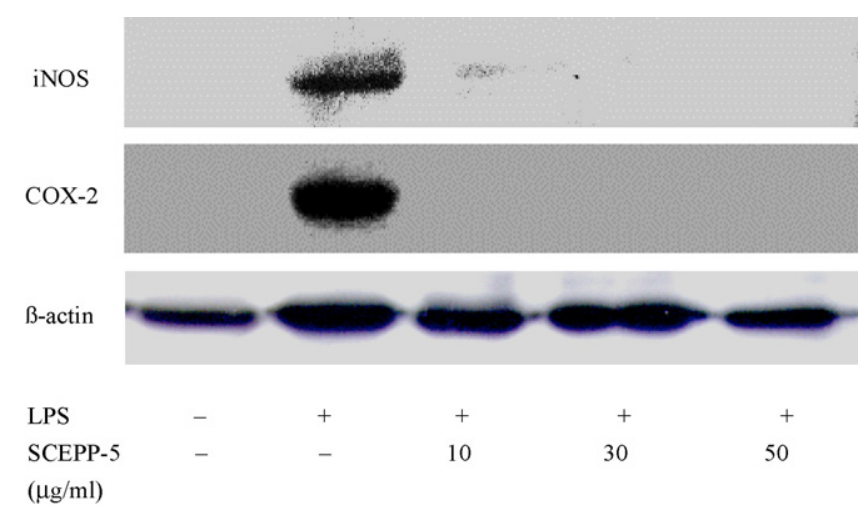

Fig. 2. Effects of SCEPP-5 on the expression of iNOS and COX-2 proteins in Raw 264.7 cells. Cells were incubated with $0,10,30$ and $50 \mu \mathrm{g} / \mathrm{ml} \mathrm{SCEPP-5}$ in the presence or absence of LPS $(1 \mu \mathrm{g} / \mathrm{ml})$ for $24 \mathrm{~h}$. Protein $(50 \mu \mathrm{g})$ from each sample was resolved in 10\% SDS-PAGE, and then analyzed by Western blotting assay. $\beta$-Actin was as a positive control.

for $24 \mathrm{~h}$. Western blotting analysis indicated that iNOS and COX-2 expression was up-regulated after LPS-stimulation. However, co-treatment of cells with LPS plus SCEPP-5 at tested concentrations markedly inhibited the iNOS and COX-2 expression (Fig. 2).

\section{Discussion}

The present study demonstrated that variation in methods of preparation and extraction procedures could result in a different pattern of active compounds and different magnitude of pharmacological activities. Consistent with other studies, SFE affords an advantage over more conventional extraction techniques (Palma and Taylor, 1999), as its extracts exhibited a higher antioxidant power than extracts obtained by other classical methods (Tipsrisukond et al., 1998). In this study, the optimal condition for SFE- $\mathrm{CO}_{2}$ extraction of PP material was found to be at $400 \mathrm{bar}$ pressure at $60^{\circ} \mathrm{C}$ and with $5 \%$ ethanol as a mixing modifier. The yield of extracts can be substantially increased by using $5 \%$ of ethanol as modifier.

Flavonoids and polyphenolic compounds have been shown to possess antioxidant and anti-inflammatory properties (Middleton et al., 2000). Our results showed that total flavonoids and phenolic compounds were enriched in the SCEPP-5. Studies have indicated that the use of organic solvent with SFE- $\mathrm{CO}_{2}$ extraction can increase the efficiency in isolating phenolic compounds from grape seeds (Ashraf-Khorassani and Taylor, 2004; Palma and Taylor, 1999). SFE- $\mathrm{CO}_{2}$ extraction with solvent modifier has been shown to be effective in extracting flavonoids from Scutellaria lateriflora (Bergeron et al., 2005).

In this study, different extracts of PP and $\alpha$-tocopherol were demonstrated to possess potent antioxidant activities. Pretreatment with $\alpha$-tocopherol, which functions as a free radical quencher in biological cells, can lower oxidative stress (John et al., 2001). Enzymatic formation of superoxide anions was estimated by reduction of cytochrome $c$. Xanthine oxidase converts hypoxanthine to xanthine and then to uric acid in the presence of molecular oxygen to yield superoxide anion and hydrogen peroxide. These free radicals can directly reduced ferri-cytochrome $c$ to ferro-cytochrome $c$ (Gohil et al., 2000). This suggests that extracts or compounds, which could inhibit superoxide anion regeneration, are potentially beneficial in ischaemia and edema (Lin et al., 1998).

The inhibitory ability of SCEPP-5 on the xanthine oxidase activity was slightly higher than EEPP. SFE- $\mathrm{CO}_{2}$ technique has been shown to be effective in extracting antioxidant substances from the sage and rosemary (Daukšas et al., 2001; Leal et al., 2003). Studies also showed that SFE- $\mathrm{CO}_{2}$ extract obtained from Cordyceps sinensis possesses strong xanthine oxidase inhibitory activity (Wang et al., 2005). In general, antioxidant activities of different extracts are associated with specific substances. The SFE- $\mathrm{CO}_{2}$ extract of Cordyceps sinensis antioxidant activity was identified with the presence of polysaccharides and nucleosides (Shin et al., 2001). In SCEPP-5, its antioxidant activities could be attributed to the presence of flavonoids and polyphenols.

Chronic inflammation and infections may up-regulate a series of enzymes and signaling gene proteins in affected tissues and cells. Among these pro-inflammatory enzymes, iNOS and COX2, which are responsible for increasing the levels of $\mathrm{NO}$ and $\mathrm{PGE}_{2}$, respectively, are known to be involved in the pathogenesis of many chronic diseases including multiple sclerosis, Parkinson's and Alzheimer's diseases, and cancer, etc. (Heiss et al., 2001). The SFE- $\mathrm{CO}_{2}$ extracts of Perna canaliculus exhibited anti-inflammatory activity in animal and clinical studies (Halpern, 2000). The data indicated that SCEPP-5 possessed a strong anti-inflammatory activity in Raw 264.7 cells. LPS injection stimulated plasma and tissue cytokine formation, leading to a markedly enhanced expression of iNOS with consecutive generation of a large amount of $\mathrm{NO}$, as indicated by elevated plasma and tissue levels of nitrate/nitrite concentrations (Höcherl et al., 2002; Landry and Oliver, 2001). NO synthesis induced by iNOS can lead to an increase in inflammatory diseases and cellular injury (Won and Park, 2005). NO and cytokines stimulate the expression of iNOS and COX-2, which consequently lead to the enhanced formation of $\mathrm{PGE}_{2}$. This has been considered as important mediators in the processes of inflammation (Ahmad et al., 2002; Smith et al., 2000). The present results demonstrated that SCEPP-5 is an effective inhibitor of LPSinduced $\mathrm{NO}$ generation and $\mathrm{PGE}_{2}$ production, as well as iNOS and COX-2 expression in Raw 264.7 cells. These findings provide evidence that SCEPP-5 possess potent anti-inflammatory activity. Its inhibition on COX-2 and iNOS expression could be therapeutically effective for preventing inflammatory diseases.

In conclusion, we have demonstrated that SCEPP-5, an extract obtained by SFE- $\mathrm{CO}_{2}$ technique, showed a higher level of flavonoid and phenol contents, and a more potent antioxidant and anti-inflammatory activities than extracts prepared from other conventional methods. SCEPP-5 is able to prevent NO generation and $\mathrm{PGE}_{2}$ release, as well as iNOS and COX-2 expression. This study has provided additional scientific evidences to confirm the therapeutic properties of PP in the traditional uses. The present findings also provide an important pharmacological background of supercritical fluid extract of Physalis peruviana, which can potentially develop into products for the prevention of aging and inflammatory related diseases. 


\section{References}

Ahmad, N., Chen, L.C., Gordon, M.A., Laskin, J.D., Laskin, D.L., 2002. Regulation of cyclooxygenase- 2 by nitric oxide in activated hepatic macrophages during acute endotoxemia. J. Leukocyte Biol. 71, 1005-1011.

Ashraf-Khorassani, M., Taylor, L.T., 2004. Sequential fractionation of grape seeds into oils, polyphenols, and procyanidins via a single system employing $\mathrm{CO}_{2}$-based fluids. J. Agric. Food Chem. 52, 2440-2444.

Bergeron, C., Gafner, S., Clausen, E., Carrier, D.J., 2005. Comparison of the chemical composition of extracts from Scutellaria lateriflora using accelerated solvent extraction and versus standard hot water or $70 \%$ ethanol extraction. J. Agric. Food Chem. 53, 3076-3080.

Bitler, C.M., Viale, T.M., Damaj, B., Crea, R., 2005. Hydrolyzed olive vegetation water in mice has anti-inflammatory activity. J. Nutr. 135, 1475-1479.

Bulkley, G.B., 1983. The role of oxygen free radicals in human disease processes. Surgery 94, 407-411.

Chang, W.S., Chang, Y.H., Lu, F.J., Chiang, H.C., 1994. Inhibitory effects of phenolics on xanthine oxidase. Anticancer Res. 14, 501-506.

Cheng, H.Y., Lin, T.C., Yu, K.H., Yang, C.M., Lin, C.C., 2003. Antioxidant and free radical scavenging activities of Terminalia chebula. Biol. Pharm. Bull. 26, 1331-1335.

Cliffe, S., Fawer, M.S., Maier, G., Takata, K., Ritter, G., 1994. Enzyme assays for the phenolic content of natural juices. J. Agric. Food Chem. 42, 1824-1828.

Crofford, L.J., Lipsky, P.E., Brooks, P., Abramson, S.B., Simon, L.S., Van de Putte, L.B., 2000. Basic biology and clinical application of specific cyclooxygenase-2 inhibitors. Arthritis Rheum. 43, 4-13.

Daukšas, E., Venskutonis, P.R., Povilaityte, V., Sivik, B., 2001. Rapid screening of antioxidant activity of sage (Salvia officinalis L.) extracts obtained by supercritical carbon dioxide at different extraction conditions. Nahrung Food $45,338-341$

Dormandy, T.L., 1983. An approach to free radicals. Lancet 11, 1010-1014.

Ganey, P.E., Barton, Y.W., Kinser, S., Sneed, R.A., Barton, C.C., Rothol, R.A., 2001. Involvement of cyclooxygenase-2 in the potentiation of allyl alcoholinduced liver injury by bacterial lipopolysaccharide. Toxicol. Appl. Pharmacol. 174, 113-121.

Gohil, K., Moy, R.K., Farzin, S., Maguire, J.J., Packer, L., 2000. mRNA expression profile of a human cancer cell line in response to Ginkgo biloba extract induction of antioxidant response and the Golgi system. Free Radic. Res. $33,831-849$.

Halpern, G.M., 2000. Anti-inflammatory effects of a stabilized lipid extract of Perna canaliculus (Lyprinol). Allergie Immunol. (Paris) 32, 272-278.

Heiss, E., Herhaus, C., Klimo, K., Bartsch, H., Gerhauser, C., 2001. Nuclear factor kappa $\mathrm{B}$ is a molecular target for sulforaphane-mediated antiinflammatory mechanisms. J. Biol. Chem. 276, 32008-32015.

Hibbs Jr., J.B., Taintor, R.R., Vavrin, Z., 1987. Macrophage cytotoxicity: role for $\mathrm{L}$-arginine deiminase and imino nitrogen oxidation to nitrite. Science 235 , 473-476.

Höcherl, K., Dreher, F., Kurtz, A., Bucher, M., 2002. Cyclooxygenase-2 inhibition attenuates lipopolysaccharides-induced cardiovascular failure. Hypertension 40, 947-953.

Hu, Q., Xu, J., Chen, S., Yang, F., 2004. Antioxidant activity of extracts of black sesame seed (Sesamom indicum L.) by supercritical carbon dioxide extraction. J. Agric. Food Chem. 52, 943-947.

John, S., Kale, M., Rathore, N., Bhatnagar, D., 2001. Protective effect of vitamin $\mathrm{E}$ in dimethoate and malathion induced oxidative stress in rat erythrocytes. J. Nutr. Biochem. 12, 500-504.

Landry, D.W., Oliver, J.A., 2001. The pathogenesis of vasodilatory shock. N. Engl. J. Med. 345, 588-595.

Leal, P.F., Braga, M.E.M., Sato, D.N., Carvalho, J.E., Marques, M.O.M., Meireles, M.A.A., 2003. Functional properties of spice extracts obtained via supercritical fluid extraction. J. Agric. Food Chem. 51, 2520-2525.
Lin, C.C., Yen, M.H., Lo, T.S., Lin, J.M., 1998. Evaluation of the hepatoprotective and antioxidant activities of Boeluneria nivea var. nivea and Boeluneria nivea var. tenacissima. J. Ethnopharmacol. 60, 9-17.

McCord, J.M., Fridovich, I., 1969. Superoxide dismutase: an enzymic function for erythrocuprein (hemocaprein). J. Biol. Chem. 244, 6049-6055.

Middleton Jr., E., Kandaswami, C., Theoharides, T.C., 2000. The effects of plant flavonoids on mammalian cells: implications for inflammation, heart disease and cancer. Pharmacol. Rev. 52, 673-751.

Mitchell, J.A., Larkin, S., Williams, T.J., 1995. Cyclooxygenase-2 regulation and relevance in inflammation. Biochem. Pharmacol. 50, 1535-1542.

Palma, M., Taylor, L.T., 1999. Extraction of polyphenolic compounds from grape seeds with near critical carbon dioxide. J. Chromatogr. A 849, 117-124.

Perry, L.M., 1980. Medicinal Plants of East and Southeast Asia-Attributed Properties and Uses. MIT Press, Cambridge, USA, p. 393.

Ramos, C.L., Pou, S., Britigan, B.E., Cohen, M.S., Rosen, G.M., 1992. Spin trapping evidence for myloperoxidase-dependent hydroxyl radical formation by human neutrophils and monocytes. J. Biol. Chem. 267, 8307-8312.

Schwarz, K., Ternes, W., Schmauderer, E., 1992. Antioxidative constituents of Rosmarinus officinalis and Salvia officinalis. III: Stability of phenolic diterpenes of rosemary extracts under thermal stress as required for technological processes. Z. Lebensm. Unter. For. 195, 104-107.

Shin, K.H., Lim, S.S., Lee, S., Lee, Y.S., Cho, S.Y., 2001. Antioxidant and immunostimulating activities of the fruiting bodies of Paecilomyces japonica, a new type of Cordyceps sp. Ann. N. Y. Acad. Sci. 928, 261273

Shu, X.S., Gao, Z.H., Yang, X.L., 2004. Supercritical fluid extraction of sapogenins from tubers of Smilax china. Fitoterapia 75, 656-661.

Smith, W.L., Dewitt, D.L., Garavito, R.M., 2000. Cyclooxygenases: structural, cellular, and molecular biology. Annu. Rev. Biochem. 69, 145-182.

Steineck, M.J., Khan, A.U., Karnovsky, M.J., 1992. Intracellular singlet oxygen generation by phagocytosing neutrophils in response to particles coated with a chemical trap. J. Biol. Chem. 267, 13425-13433.

Tipsrisukond, N., Fernando, L.N., Clarke, A.D., 1998. Antioxidant effects of essential oleoresin of black pepper from supercritical carbon dioxide extractions in ground pork. J. Agric. Food Chem. 46, 4329-4333.

Trenam, C.W., Blake, D.R., Morris, C.J., 1992. Skim inflammation reactive oxygen species and the role of iron. J. Invest. Dermatol. 99, 675-682.

Ulevtich, R.L., Tobias, P.S., 1995. Receptor-dependents mechanisms of cell stimulation by bacterial endotoxin. Annu. Rev. Immunol. 13, 437459

Wang, B.J., Won, S.J., Yu, Z.R., Su, C.L., 2005. Free radical scavenging apoptotic effects of Cordyceps sinensis fractionated by supercritical carbon dioxide. Food Chem. Toxicol. 43, 543-552.

Won, S.Y., Park, E.H., 2005. Anti-inflammatory and related pharmacological activities of cultured mycelia and fruiting bodies of Cordyceps militaris. J. Ethnopharmacol. 96, 555-561.

Wu, S.J., Ng, L.T., Chen, C.H., Lin, D.L., Wang, S.S., Lin, C.C., 2004a. Antihepatoma activity of Physalis angulata and Physalis peruviana extracts and their effects on apoptosis in human Hep G2 cells. Life Sci. 74, 2061-2073.

Wu, S.J., Ng, L.T., Lin, D.L., Wang, S.S., Lin, C.C., 2004b. Physalis peruviana extract induces apoptosis in human Hep G2 cells through CD95/CD95L system and the mitochondrial signaling transduction pathway. Cancer Lett. 215, 199-208.

Wu, S.J., Ng, L.T., Huang, Y.M., Lin, D.L., Wang, S.S., Huang, S.N., Lin, C.C., 2005. Antioxidant of Physalis peruviana. Biol. Pharm. Bull. 28, 963-966.

Yang, C., Xu, Y.R., Yao, W.X., 2002. Extraction of pharmaceutical components from Ginkgo biloba leaves using supercritical carbon dioxide. J. Agric. Food Chem. 50, 846-849.

Zou, Y.P., Lu, Y.H., Wei, D.Z., 2004. Antioxidant activity of a flavonoid-rich extract of Hypericum perforatum L. in vitro. J. Agric. Food Chem. 52, 5032-5039. 